\title{
Journal of Information and Knowledge Management
}

\section{Template-driven Best Practice Documentation}

\begin{abstract}
Knowledge Management has become a key instrument for identifying, creating and sharing organizational knowledge assets. An attractive means for sharing knowledge is Best Practices (BPs), which are proven as well as efficient and effective solutions to recurring problems. BPs can offer significant benefits, including improved performance, reduced re-work and cost savings. However, the implementation of BPs raises several challenges, one of which is that the low quality of BP documentation can impede the use of BPs. One way to address this challenge is by supporting designers in structuring BP documents so that they become complete, uniform and easy-to-use. This support can take the form of a BP Document Template that prescribes the structure of BP documents by defining relevant attributes for describing BPs. This paper proposes a comprehensive and practical BP Document Template for supporting the creation, use and evaluation of BP documents. The design of this template is an example of design science research including requirements elicitation, artifact development, demonstration, and evaluation. The development is based on a combination of expert interviews and a literature study using Grounded Theory, while the demonstration applies the proposed template in three real-life cases, and the evaluation is based on expert interviews. The proposed BP Document Template consolidates, integrates and extends previous work on BP documentation. It thereby offers an effective tool for BP designers, managers, and users that can support them in the design, evaluation and application of BPs.
\end{abstract}

\section{Keywords}

Knowledge Management, Knowledge Sharing, Best Practice, Best Practice Documentation, Best Practice Document Template.

\section{Introduction}

As institutions and societies become ever more complex, organizations need to develop strategies for identifying, creating, sharing and applying their knowledge assets by means of Knowledge Management (KM) (Dalkir, 2011). One of the most widely used means to share knowledge is via Best Practices (BP). A BP can be defined as "the most efficient (least amount of effort) and effective (best results) way of accomplishing a task, based on repeatable procedures that have proven themselves over time for large numbers of people" (cited from Wikipedia in Graupner et al., (2009)). The use of BP to share knowledge has been 
a popular means for the past two decades and has helped organizations to move towards higher performance (Whittle et al., 1992; Szulanski, 1996; O’Dell \& Grayson, 1998; Davies \& Kochhar, 2002; Netland \& Alfnes, 2011; Watson, 2007).

Sharing BPs can affect a company's performance in a number of ways, such as return on investment, value added per employee, and customer satisfaction (Goodman \& Goldman, 2007; Pfeffer \& Sutton, 2006; Gold et al., 2001). Reddy and McCarthy (2006) identified benefits that organizations may gain through effective sharing of BPs: "1) identify and replace poor practices; 2) raise the performance of poor performers closer to that of the best; 3) avoid reinventing the wheel; 4) minimize re-work caused by the use of poor methods; 5) save costs through better productivity and efficiency". While BPs can offer many benefits, there is still a risk that organizations fail with their BP initiatives (Barrett \& Stanley, 1999; Whittle et al., 1992; Davies \& Kochhar, 2000). A main challenge for such initiatives is that the low quality of BP documentation can impede the use of BPs (Dana \& Smyrnios, 2010).

Low-quality BP documentation leads to situations in which practitioners are not able to correctly and efficiently use BPs, or may not be prepared to rely on them. Hence, low-quality BP documentation can prevent using BPs as a means of knowledge sharing. Several researchers have emphasized that the lack of understanding the purpose of a BP, as well as failing to measure the value of its knowledge, are major barriers to successfully managing knowledge (Tabrizi et al., 2011; Aggestam \& Persson, 2010; Dyer \& McDonough, 2001).

Renzl et al., (2006) emphasized that knowledge can be shared smoothly if and only if it is correctly and completely documented. Such documentation often takes the form of Best Practice Documents (BPDs), which are structures that describe BPs. BPDs in organizations reside in various forms, such as structured documents in binders and electronic databases, and as unstructured documents in the forms of memos, manuals, notes, meetings minutes, etc (Jashapara, 2011).

A key instrument for supporting the design, evaluation, management and use of BPDs is the BP document template. Such a template offers a format for structuring and organizing BPDs by means of pre-specified attributes or fields, such as "Title of the BP", "Author of the BP", and "Description of the BP". An early work on BPDs was that by Shull and Turner (2005), who proposed an approach to document the context and results of using BPs. This approach aimed to provide a means to better estimate the effectiveness of a practice for a user by describing the BPs in a uniform way supported by available evidence. Bubenko et al., (2001) proposed a detailed BP template. It consisted of 16 fields: name, problem, context forces, solution, rationale, consequences, related information, known applications, author, also known as (i.e. synonyms), examples, usage elements, type, domain, and keywords. Renzl and his colleagues (2006) suggested the following sections for a BP documentation template: title, profile, context, resources, description, lessons learned, links to resources, and tools and techniques. 
Another solution, similar to ours, was presented by Dani et al., (2006). Their solution aims to make BP knowledge more readily transferable. It structures attributes for describing BPs in two broad categories: process and implementation. The process attributes are process specific knowledge (e.g. a process flow diagram representing the BP and resources needed for carrying out the BP), performance measure knowledge (e.g. metrics to measure the performance of the BP), enabler knowledge (e.g. tools and technique supporting the BP), and internal expert knowledge (e.g. experts to contact to receive tacit knowledge regarding the BP). The implementation attributes are cause-effect relationship knowledge (e.g. possible positive and negative effects of the BP on different processes in the organization, including side effects); level of implementation knowledge (e.g. which effect partly respectively fully implemented BP will have); implementation infrastructure knowledge (e.g. how the BP should be applied); and examples of companies applying the best practice.

Though some work has been done on BP document templates, the area is still immature and would benefit from consolidation and integration. Therefore, this paper sets the goal to design a comprehensive and practical BP Document Template for supporting the creation, use and evaluation of BPDs. This paper presents a BP Document Template that considerably extends existing ones.

The BP Document Template of this paper is based on an attribute-value system, which is a representation framework for structured knowledge. The basic assumption of an attributevalue system is that there are objects that can be described by means of attribute-value pairs. For example, a person may exist who can be described by the attribute-value pairs <name, 'John Doe'>, <age, 33>, and <gender, male>. Attribute-value systems have been used extensively for the representation of knowledge. The assumptions and ideas behind attributevalue systems are also used in object-oriented programming, information modeling and other areas (Barsalou \& Hale 1993; Barsalou, 2003). As mentioned above, the BP Document Template consists of a set of pre-specified attributes, such as "Title of the BP" and "Description of the BP". A user of the template provides data/values for these attributes when documenting a BP. These attributes are properties of a BP or its documentation.

The work presented in this paper is an example of design science research, which is also reflected in the structure of the paper. Section 2 outlines the overall research process, which includes design as well as empirical activities. Section 3 describes a number of requirements that should be fulfilled by the BP Document Template. Section 4 describes the structure of the BP Document Template as well as the research process for constructing it, which builds on both literature studies and expert interviews. Section 5 discusses demonstration and evaluation of the template through cases and expert feedback, and Section 6 concludes the paper. 


\section{Method}

The overall research approach used in this paper is design science. According to Hevner et al., (2004), design science aims at creating artifacts for addressing practical problems as well as knowledge about them. These artifacts include methods, models, constructs, frameworks, prototypes or IT systems, which will be introduced to change and improve a practice (Johannesson \& Perjons, 2014). Thus, design science research can be seen as an activity aimed at generating artifacts and testing hypotheses about them, (Bider et al., 2012).

The research process for designing and evaluating the BP Document Template is depicted in Figure 1. The process included five research activities as defined by the design science method framework of Johannesson \& Perjons (2014):

- Explicate Problem - as the problem was given from literature, this was a marginal part of the research process

- Define Requirements - requirements were based on findings in the KM literature

- Design and Develop Artifact - the artifact design was based on a combination of a literature study using Grounded Theory and feedback from experts

- Demonstration - the artifact was tested in three real-life cases

- Evaluation - the artifact was evaluated through expert interviews

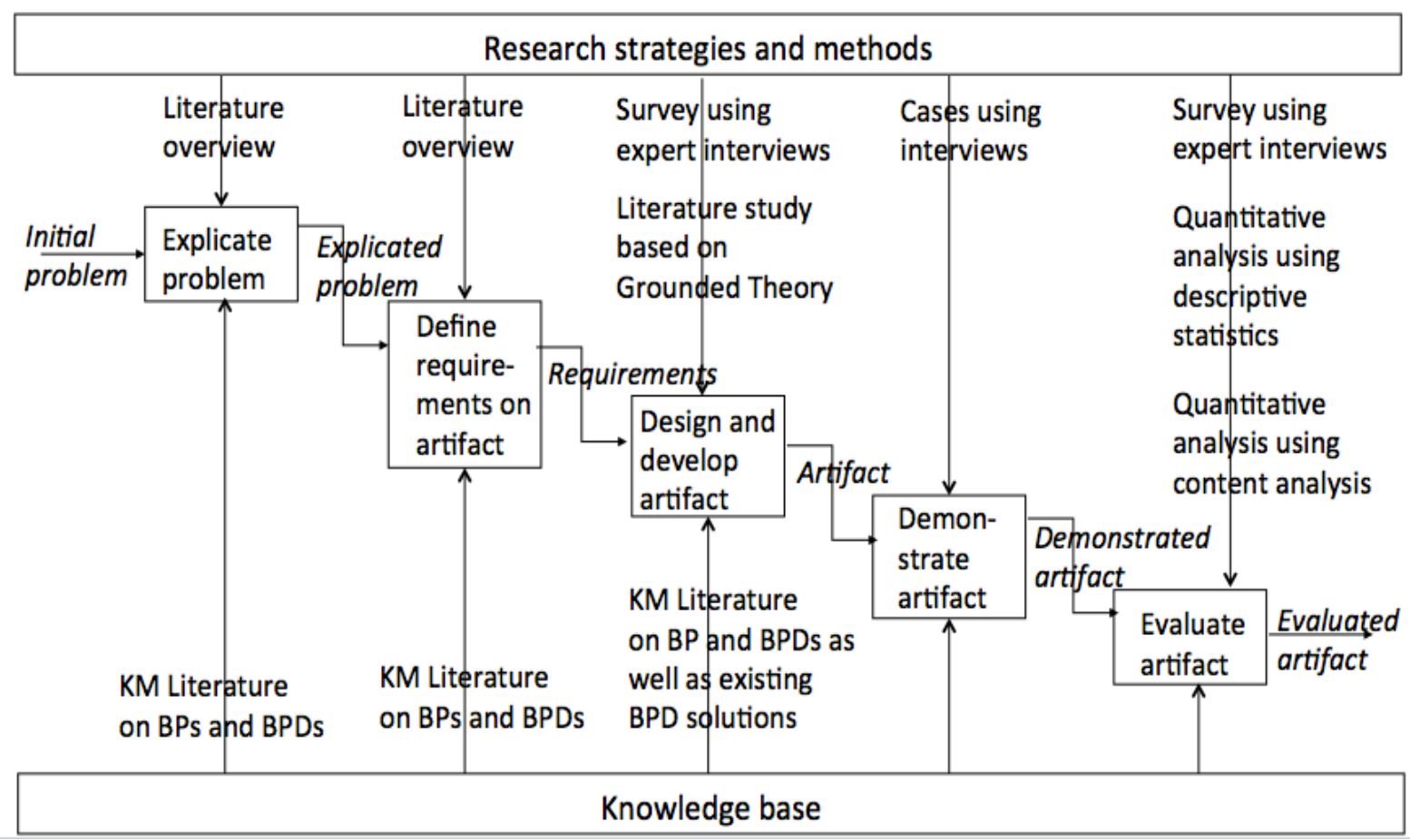

Figure 1. The activities in the design science research process of developing the BP Documents Template, including input and output between the activities (arrows from left to right), research strategies and methods applied (arrows from above), and information used from the knowledge base, i.e. research on BPs and BPDs (arrows from below) 


\section{Explicate Problem and Define Requirements}

The first activity in the design science method framework is to explicate the problem. The explicated practical problem that this paper address is:

\section{The low quality of BP documentation can impede the use of BPs in organizations}

This problem was taken from literature, where it is has been extensively discussed and analyzed, see for example, (Tabrizi et al., 2011; Aggestam \& Persson, 2010; Dyer \& McDonough, 2001; Dana \& Smyrnios, 2010, Renzl et al., 2006; Dani et al., 2006). One possible solution to address this problem is a BP Document Template that supports BP designers, managers and users in their work with BPs.

The second activity in the design science method framework is to define requirements on the artifact to be developed, i.e. requirements on the BP Document Template. These requirements do not only guide the design of the template but also its evaluation. Dautovic et al., (2011), Hargis et al., (2014), Arthur \& Stevens (1990), and ISO/IEC 26514 (2008) have identified a number of generic requirements on documentation templates. These have been used as a basis for the specific requirements for the BP Document Template.

Requirement 1: The BP Document Template shall be easy to use for practitioners in achieving their goals

A user should be able to easily use the template to achieve a particular goal. A clear documentation structure will organize information about a BP into a BPD that is easy to use (Shull \& Turner, 2005; Niwe \& Stirna, 2010; Fragidis \& Tarabanis, 2006; Motahari-Nezhad et al., 2010). The primary users for the BP Document Template are IT managers, business analysts, and business and IT developers.

Requirement 2: The BP Document Template shall support both design of high-quality BPs and evaluation of already designed BPs.

Researchers have highlighted the need of having a structure for BPD not only to facilitate design but also to evaluate already designed BPs (Smith et al., 2010; Fragidis \& Tarabanis, 2006; Graupner et al., 2009; Motahari-Nezhad et al., 2010).

Requirement 3: The BP Document Template shall consist of a complete set of BP attributes to achieve its defined goal.

Completeness means the degree to which an artifact includes all the components that are required to achieve its defined goal. Complete documentation of a BP is vital for people being able to apply it successfully (Dinur et al., 2009; Vesely, 2011; Motahari-Nezhad et al., 2010; Mansar \& Reijers, 2007). 


\section{Design and Development of the BP Document Template}

The third activity in the design science method framework is the design and development of the artifact. The BP Document Template was developed using two complementary processes, see Figure 2, each one resulting in a tentative BP Document Template. These two tentative templates were then merged into the Final BP Document Template.

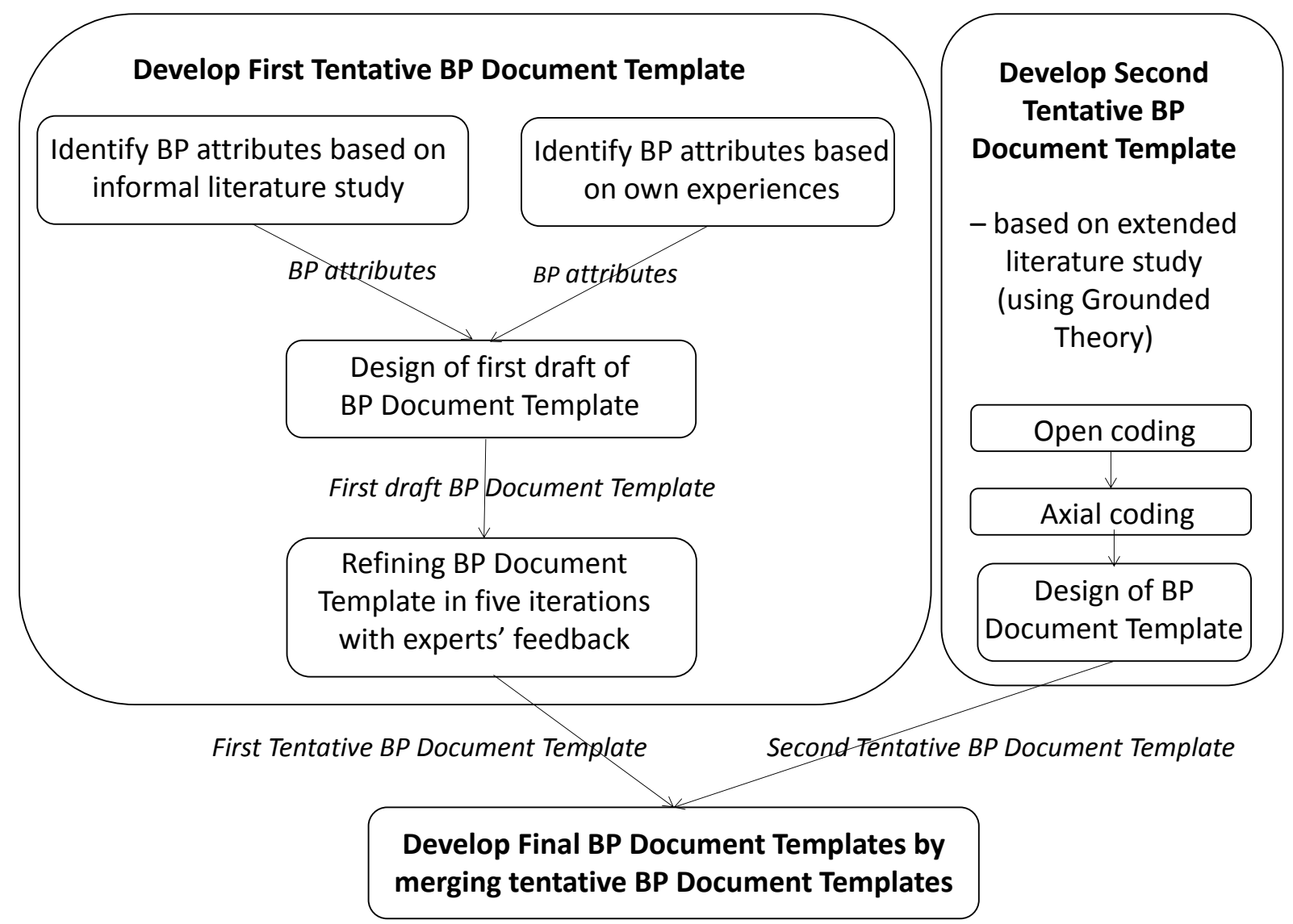

Figure 2. The research process for the development of the Final BP Document Template via two tentative BP Document Templates

\subsection{Expert Based Development of First Tentative BP Document Template}

The main thrust of the expert based development process was to elicit input from KM experts in order to identify relevant components of a BP Document Template. One of the main challenges for the process was to obtain comprehensive and detailed suggestions from the experts. In order to nudge, or trigger, the experts to provide suggestions, we provided them with an initial template, which was then iteratively extended and improved based on feedback from the experts. Thus, the development process was carried out in three main steps:

1. The first step was to conduct an informal literature review. The literature review focused on papers describing BP documentation and attributes. The search terms, used in various combinations, were "quality measures", "criteria" and "guidelines", and "best practices" as well as similar terms. The search was carried out over various 
e-resources, which included journals and international conferences related to KM. The e-resources selected were ACM Digital Library, Emerald, Science-Direct (Elsevier), SpringerLink, Wiley, IEEE Xplore, Google Scholar and AISeL. Based on this, ten articles that included BP attributes were identified.

2. The second step was to design a tentative BP Document Template based on results from the literature review as well as our experience. The experience-based input was based on our research in KM and enterprise modeling, in particular designing and applying BPs. The developed tentative artifact consisted of $37 \mathrm{BP}$ attributes that were grouped into ten categories.

3. The third step was to evaluate and refine the tentative BP Document Template in five refinement phases. In each phase, one or two practitioners or academic experts were asked to evaluate and refine the template, and based on their input, attributes were added, deleted or refined. In total, Interviews were carried out with seven practitioners and academic experts in the area of BP. Purposive sampling was applied to select the participants. The selected participants were identified based on their expertise in KM and based on one of the researcher's contact in Stockholm University and Uppsala University. Based on the respondents' feedback and suggestions, the First Tentative BP Document Template was designed consisting of 30 attributes (Alwazae et al., 2014). The First Tentative BP Document Template can be found in Appendix I.

\subsection{Literature Based Development of Second Tentative BP Document Template}

The development of the Second Tentative Document Template was carried out through a literature review based on Grounded Theory. Grounded Theory was considered to be the most appropriate method for analysis, as the purpose of the study was to identify BP attributes without any preconceptions. The literature review followed the five phases and detailed steps proposed by Wolfswinkel et al., (2013), as shown in Figure 3. 


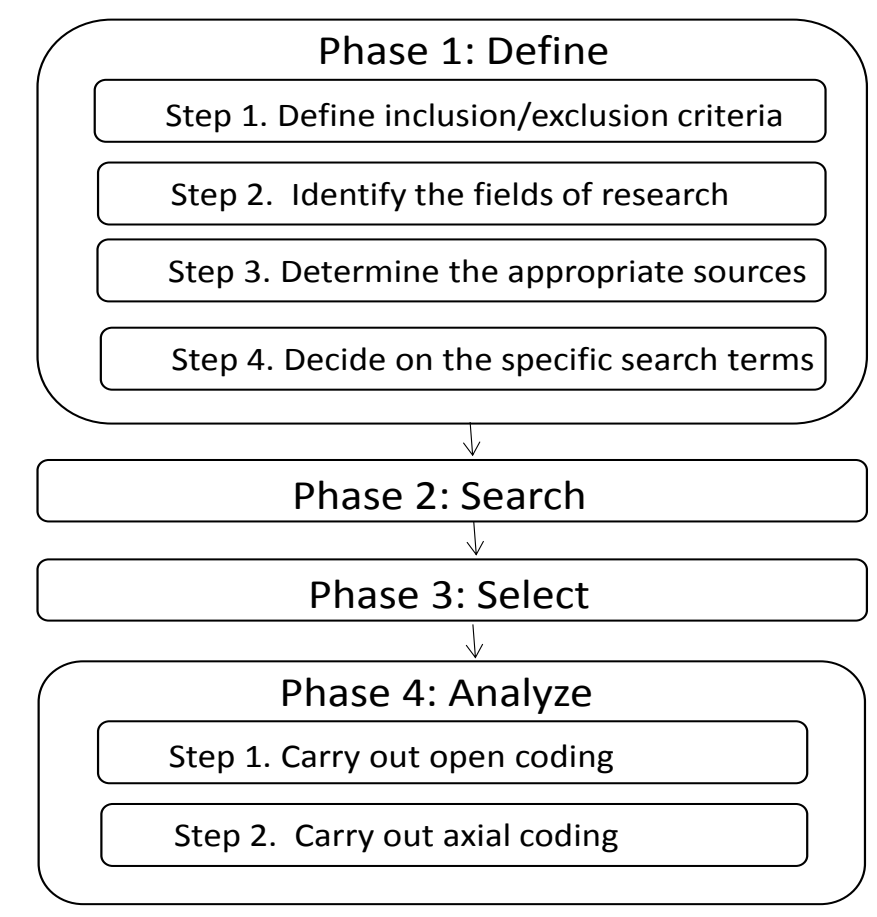

Figure 3. The phases and steps of the literature review based on Grounded Theory (Wolfswinkel et al., 2013)

\section{Phase 1. Define}

The Define phase is about setting the scope for the literature review.

Step 1: Define the inclusion and exclusion criteria for searching for articles

The researchers identified a number of inclusion and exclusion criteria for articles, see Table 1.

Table 1. Inclusion and exclusion criteria for article search.

\begin{tabular}{|l|l|}
\hline Inclusion criteria & Exclusion criteria \\
\hline $\begin{array}{l}\text { Article is included if it focuses on } \\
\text { documenting BP in KM }\end{array}$ & $\begin{array}{l}\text { Article is excluded if it is based only on } \\
\text { expert opinion, or it presents opinions, } \\
\text { editorials, and commentaries }\end{array}$ \\
\hline $\begin{array}{l}\text { Article is included if it is based on } \\
\text { empirical data and theoretical reviews }\end{array}$ & $\begin{array}{l}\text { Article is excluded if it is a preliminary } \\
\text { conference version of included journal } \\
\text { papers }\end{array}$ \\
\hline $\begin{array}{l}\text { Article is included if it is published within } \\
\text { the last two decades, i.e. from 1994 } \\
\text { onwards }\end{array}$ & \\
\hline
\end{tabular}




\section{Step 2. Identify the fields of research}

As IS is an interdisciplinary field, (Webster \& Watson, 2002), the researchers identified the field of the study as IS and Management and Systems Thinking. Those fields have also been proposed by Guo and Sheffield (2008) in their study for a paradigmatic and rigorous examination of KM research.

\section{Step 3. Determine the appropriate sources}

These sources included journals and international conferences related to $\mathrm{KM}$ found in the following e-resources/databases: ACM Digital Library, ProQuest, Emerald, Sage, ScienceDirect (Elsevier), SpringerLink, Wiley, IEEE Xplore, Google Scholar and Association for Information Systems Electronic Library (AISeL). These e-resources/databases were primarily selected because they included relevant journals and conferences focusing on IS, management and systems thinking.

\section{Step 4. Decide on the specific search terms}

The search terms used were "best practice", "best practices", "good practices", "recommended practices", "practice quality measures", "practice success factors", "practice template" and "practice documentation".

\section{Phase 2. Search}

Search means browsing and examining e-resources/databases, i.e. the actual search through all the identified sources. This resulted in 470 candidate articles to be considered in the next phase.

\section{Phase 3. Select}

The third phase was to select the most relevant articles, which was done using the inclusion and exclusion criteria of Table 2.

Table 2. Inclusion and exclusion criteria for article selection.

\begin{tabular}{|l|l|}
\hline Inclusion criteria & Exclusion criteria \\
\hline $\begin{array}{l}\text { Article is included if it focuses on } \\
\text { documentation features, properties, or BP } \\
\text { attributes }\end{array}$ & $\begin{array}{l}\text { Article is excluded if it is not based on or } \\
\text { does not have any scientific contributions } \\
\text { that were characterized by a specific and } \\
\text { clear research method, how it was } \\
\text { processed, and how data were collected } \\
\text { and applied. }\end{array}$ \\
\hline
\end{tabular}


Article is included if it focuses on
motivating
and implementation or application of BP

Article is included if it focuses on adapting, storing and saving BP knowledge

The articles needed to fulfill at least one of the three inclusion criteria in Table 2 for being included. Based on these criteria, the number of articles was reduced to 31 .

\section{Phase 4. Analyze}

In the analyze phase, the researchers studied the contents of the 31 collected articles and took relevant excerpts related to BP attributes. In total, 272 excerpts were collected, which were organized using Dedoose software (Dedoose, 2015) in order to support tracking and analysis. The data were segmented and organized into categories and sub-categories using codes created by the researchers during the analysis (Lewins \& Silver, 2007). Open and axial coding were carried out, as described below. However, no selective coding was performed, as the goal of the literature review only was to provide a basis for the BP Document Template.

\section{Step 1. Carry out open coding}

Open coding is the activity where the "researchers engage in conceptualizing and articulating the often hidden aspects of a set of excerpts that they noted earlier as relevant during their close reading of a set of single studies" (Wolfswinkel et al., 2013). The open coding started by re-reading the collected set of excerpts. Then, the researchers derived concepts from those excerpts. In the beginning of the ongoing coding, they generated many ideas and concepts inductively from the excerpts, which were later refined. Thus, they identified 68 BP attributes.

\section{Step 2. Carry out axial coding}

Axial coding is the activity where "the interrelations between categories and their subcategories (including their properties) are identified" (Wolfswinkel et al., 2013). In this step, similar codes were grouped together into categories and sub-categories. The initially proposed sub-categories were "Success Factor, Management Success Factor, Content Success Factor, BP Driver, Documenting Form of BP, and System Support”.

The coding was an iterative process, where the researchers compared and contrasted the generated attributes and sub-categories with their relevant excerpts. They delineated the boundary between similar BP attributes to facilitate understanding of the attributes and removed irrelevant attributes given the research goal. In the end, 24 BP attributes were identified with their supporting excerpts. Since axial coding requires relating narrow codes to 
broader categories, the researchers identified and renamed nine sub-categories (Document Metadata, Presentation Structure, BP Actor Resource, User Relationship, Internal BP Characteristics, Problem Relationship, BPs Relationships, Application, and Evaluation). The Second Tentative BP Document Template can be found in Appendix II while Appendix III provides information about in which articles the attributes have occurred. The term "subcategory" was replaced with the term "component".

\subsection{Merging the Tentative BP Document Templates}

After their construction, the First Tentative BP Document Template and the Second Tentative BP Document Template were merged in order to arrive at the Final BP Document Template, which is shown in Table 3. The Final Template consists of 33 attributes including nine attributes (out of 30) from the First Tentative BP Document Template and 24 attributes (out of 24 attributes) from the Second Tentative BP Document Template. This means that 21 attributes (out of 30) from the First Tentative Template were not added to the Final BP Document Template. Of these 21 attributes, 15 attributes had a similar meaning as attributes in the Second Tentative Template, while six attributes were aimed to be used mainly for indexing BPs as presented in Appendix IV.

Table 3. The Final BP Document Template

\begin{tabular}{|c|c|c|}
\hline Component & Attribute & Description \\
\hline \multirow{2}{*}{$\begin{array}{l}\text { Summary of } \\
\text { BP }\end{array}$} & 1. Title & An identifying name for the BPD \\
\hline & 2. Summary & $\begin{array}{l}\text { A short description of the contents of the } \\
\text { BPD }\end{array}$ \\
\hline \multirow[t]{4}{*}{$\begin{array}{l}\text { BP } \\
\text { Representa- } \\
\text { tion }\end{array}$} & 3. Pattern Attributes & $\begin{array}{l}\text { Contains attributes often used in pattern } \\
\text { descriptions, such as problem, solution, } \\
\text { and context }\end{array}$ \\
\hline & $\begin{array}{l}\text { 4. Author Contact } \\
\text { Information }\end{array}$ & $\begin{array}{l}\text { Information about the authors of the BPD, } \\
\text { including, name, address, and e-mail }\end{array}$ \\
\hline & $\begin{array}{l}\text { 5. Revision } \\
\text { Information }\end{array}$ & $\begin{array}{l}\text { Information about all previous versions of } \\
\text { the BPD }\end{array}$ \\
\hline & $\begin{array}{l}\text { 6. Reviews } \\
\text { Information }\end{array}$ & $\begin{array}{l}\text { Information about reviews of the BPD with } \\
\text { URLs or other pointers }\end{array}$ \\
\hline \multirow{6}{*}{$\begin{array}{l}\text { Requirements } \\
\text { for Applying } \\
\text { BP }\end{array}$} & 7. Goal & The intended effect of applying the BP \\
\hline & 8. Means & $\begin{array}{l}\text { The means that are needed for applying the } \\
\text { BP, including people and technology }\end{array}$ \\
\hline & 9. Skills & $\begin{array}{l}\text { The skills and competence required of the } \\
\text { end-user for applying the BP }\end{array}$ \\
\hline & 10. Cost & $\begin{array}{l}\text { An estimation of the costs for applying the } \\
\text { BP }\end{array}$ \\
\hline & 11. Barriers & $\begin{array}{l}\text { Obstacles or problems that may occur } \\
\text { before, during, and after applying the BP }\end{array}$ \\
\hline & $\begin{array}{l}\text { 12. Barrier } \\
\text { management }\end{array}$ & $\begin{array}{l}\text { Procedures to follow if certain obstacles or } \\
\text { problems are encountered }\end{array}$ \\
\hline BP Actor & 13. Community & Community of practice that may be \\
\hline
\end{tabular}




\begin{tabular}{|c|c|c|}
\hline & Practice & interested in using the BP \\
\hline & 14. Champion & $\begin{array}{l}\text { The need and role of a champion for the } \\
\text { BP }\end{array}$ \\
\hline & 15. Owner & $\begin{array}{l}\text { The BP owner or responsible who might } \\
\text { be an individual, role, department or } \\
\text { organization }\end{array}$ \\
\hline & 16. Training needs & $\begin{array}{l}\text { The degree to which a person has to be } \\
\text { trained in order to use the BP }\end{array}$ \\
\hline & 17. Acceptability & $\begin{array}{l}\text { The degree of BP acceptance by domain } \\
\text { experts for resolving the problem } \\
\text { addressed by the BP }\end{array}$ \\
\hline \multirow[t]{11}{*}{ BP Properties } & 18. Usability & The degree to which the BP is easy to use \\
\hline & $\begin{array}{l}\text { 19. Comprehen- } \\
\text { siveness }\end{array}$ & $\begin{array}{l}\text { The degree to which the BP offers a } \\
\text { comprehensive and complete view of the } \\
\text { problem and solution under consideration }\end{array}$ \\
\hline & 20. Relevance & $\begin{array}{l}\text { The degree to which the problem } \\
\text { addressed by the BP is experienced as } \\
\text { significant by practitioners }\end{array}$ \\
\hline & 21. Justification & $\begin{array}{l}\text { The degree to which evidence shows that } \\
\text { the BP solves the problem }\end{array}$ \\
\hline & 22. Prescriptiveness & $\begin{array}{l}\text { The degree to which the BP offers a } \\
\text { concrete proposal for solving the problem }\end{array}$ \\
\hline & 23. Coherence & $\begin{array}{l}\text { The degree to which the BP constitutes a } \\
\text { coherent unit, i.e. all parts are clearly } \\
\text { related }\end{array}$ \\
\hline & 24. Consistency & $\begin{array}{l}\text { The degree to which the BP is consistent } \\
\text { with existing knowledge and vocabulary } \\
\text { used in the target industry sector or } \\
\text { knowledge domain }\end{array}$ \\
\hline & 25. Granularity & $\begin{array}{l}\text { The degree to which the BPD is } \\
\text { appropriately detailed }\end{array}$ \\
\hline & 26. Adaptability & $\begin{array}{l}\text { The degree to which the BP can be easily } \\
\text { modified and adapted to other situations }\end{array}$ \\
\hline & 27. Activity & The tasks to be carried out in the BP \\
\hline & 28. Integration & $\begin{array}{l}\text { The degree to which the BP is integrated } \\
\text { with other BPs and KM components }\end{array}$ \\
\hline \multirow{5}{*}{$\begin{array}{l}\text { BP } \\
\text { Implemen- } \\
\text { tation }\end{array}$} & $\begin{array}{l}\text { 29. Demonstration of } \\
\text { Success }\end{array}$ & $\begin{array}{l}\text { A case where the BP is successfully } \\
\text { demonstrated }\end{array}$ \\
\hline & 30. Installation Time & $\begin{array}{l}\text { The time it takes to introduce and } \\
\text { implement the BP in an organization }\end{array}$ \\
\hline & 31. Application Time & $\begin{array}{l}\text { The time it takes to apply the BP in an } \\
\text { organization }\end{array}$ \\
\hline & $\begin{array}{l}\text { 32. Experiences and } \\
\text { Feedback }\end{array}$ & $\begin{array}{l}\text { Users' opinions, advice and experiences of } \\
\text { the BP }\end{array}$ \\
\hline & 33. Measurement & $\begin{array}{l}\text { Indicators for measuring the quality and } \\
\text { performance of the BP }\end{array}$ \\
\hline
\end{tabular}




\section{Demonstration and Evaluation of the BP Document Template}

This section presents the fourth activity in the design science method framework that is demonstration of the artifact. Also, it presents the fifth activity in the design science method framework that is evaluation of the artifact.

\subsection{Demonstration}

The Final BP Document Template was applied in three real-life cases in three different organizations in order to demonstrate its feasibility. Three experts, one from each of the organizations, were asked to apply the BP Document Template using two or more BPDs existing in the organization. After the application, semi-structured interviews were carried out with the experts regarding the benefits and drawbacks of applying the template. More precisely, questions were asked about which attributes were not used in the organizations' existing BPDs; which attributes were difficult to apply and why; overall opinions and obstacles of applying the BP Document Template and whether the experts had any improvements to suggest.

\section{The first real-life case}

The first real-life case was carried out in a global organization within the oil domain with over 10000 employees operating in 37 countries. In the organization, BPs were used as an important tool for knowledge sharing. The expert applying the BP Document Template was a $\mathrm{KM}$ consultant and responsible for developing KM strategy and KM solutions within the organization, including a knowledge resource portal for information and knowledge sharing. The expert and his colleagues applied the BP Document Template on two BPDs used in the organization.

First, The BP Document Template was customized in order to make it suitable for the organization at hand. This was done by adding the following attributes to the template: project number and name, keywords, effective date, next review date, accountable function, accountable discipline, functional areas, sub-functional areas, technology platform, research and development platform, applicable process, co-authors and co-contributors.

The expert stated that nine BP attributes were not used in the organization's BPDs (skills, community of practice, training needs, acceptability, comprehensiveness, relevance, demonstration of success, installation time and application time). The expert claimed that they had difficulty to apply five attributes (i.e. skills, community of practice, training needs, acceptability, and comprehensiveness) due to lack of information in their BPDs. The expert stressed the difficulty to identify and specify data/values for some of the attributes if the users do not know for which situation and audience the BP is documented. One such attribute is skills.

\section{Second real-life case}


The second case was carried out in a global organization within the IT domain with more than 1000 employees operating mainly in Europe and Asia. The expert applying the BP Document Template was a KM consultant responsible for improving the way people communicated, directly or through IT. The expert applied the template on three BPDs used in the organization.

The expert stated that $12 \mathrm{BP}$ attributes (goal, means, skills, costs, training needs, usability, activity, integration, demonstration of success, installation time, application time and measurement) from the BP Document Template did not occur in the organization's BPDs. The expert had difficulty to apply nine attributes (i.e. goal, barriers, usability, comprehensiveness, justification, coherence, adaptability, demonstration of success and measurement) due to lack of information in their BPDs. The expert emphasized the difficulty of specifying the data/values for some attributes because post action feedback was not applied in the organization. One such attribute was justification. Another problem was that the documentation of data/values for some attributes became rather subjective.

\section{Third real-life case}

The third case was carried out in a national organization with more than 500 employees within the IT industry. The expert applying the BP document template was a KM manager with expertise in innovation, change management, strategy development, business processes improvement and IT consulting. The expert applied the BP Document Template on three BPDs used in the organization.

The expert stated that six BP attributes (skills, barriers, community of practice, champion, usability, and granularity) did not occur in their BP documents. The expert had difficulty applying six attributes (i.e. skills, barriers, champion, usability, coherence, granularity, and adaptability) due to lack of information in their BPDs. This expert also emphasized the difficulty of documenting data/values for attributes that become rather subjective.

\section{Experts' overall opinions}

The three experts agreed that the BP Document Template represented a good foundation to structure and articulate BPDs, and that it was relatively straightforward to use. However, the experts provided some concerns about applying the template in full scale: 1) people need to be encouraged to fill out 33 elements since it requires some time to do that; 2) the often informal and loose structure of existing BPDs makes is difficult to structure the BPDs according to the template; 3) there is a need for technical support for applying the BP document template. Two experts suggested the creation of a KM tool for applying the BP Document Template that included clear instructions and examples for its application. 


\subsection{Evaluation}

The BP Document Template was evaluated by means of expert interviews. The research strategy and methods used are depicted in Figure 4. Purposive sampling was applied to select respondents with relevant knowledge and experience. Each respondent was at an organizational level that ensured his/her awareness of the organization's strategies. Furthermore, each respondent was either from business or IT domains and should be interested in KM. Each respondent also had at least two years working experiences in the same organization with involvement in different projects. In order to identify participants, the researcher subscribed with Premium Executive subscription to LinkedIn, which made it possible to gain direct access to the respondents and contact them for participation in the study. The researcher invited 103 experts to participate in the study by sending them a letter to their inbox in LinkedIn. Finally, the researcher conducted 16 interviews.

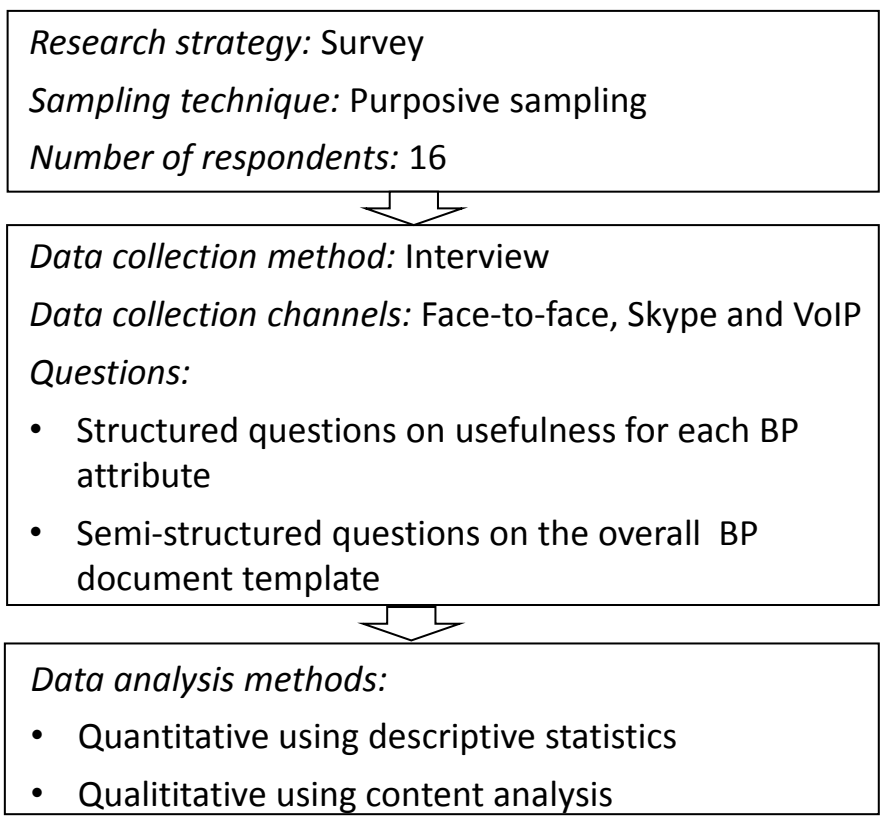

Figure 4. The research strategy and methods used in the evaluation

The data collection method used to collect the primary data was interviews, which included both structured and semi-structured parts. The structured part was for evaluating the requirements on each BP attribute and value, while the semi-structured part was for evaluating the BP Documentation Template in general. The interviews were carried out in the form of telephone interviews and face-to-face interviews. Only one participant did not allow audio recording, while the remaining 15 interviews were audio recorded. All these 15 interviews were transcribed. Field notes were taken during the unrecorded interview.

Each respondent was asked a number of structured questions about the BP attributes of the BP Document Template. The respondents assessed the usefulness of the template, using a value between 1 and 5 , where $1=$ Not useful and $5=$ Very useful. Each respondent was also asked nine semi-structured questions about the BP Document Template. The questions 
primarily addressed benefits and drawbacks of the template as well as suggestions for addition or removal of some of the BP attributes.

The overall assessed average value for the usefulness of the 33 attributes in the BP Document Template is shown in Figure. 5. The assessment revealed that the BP Document Template has useful attributes to design high-quality description of BPs. Some of the attributes received high assessment from the experts and these are title, summary, activity, justification, measurement, owner, goal, barriers, barrier management, integration, and experiences and feedback, respectively. The BP attributes that were the lowest assessed were costs, granularity, usability, coherence, acceptability, and relevance.

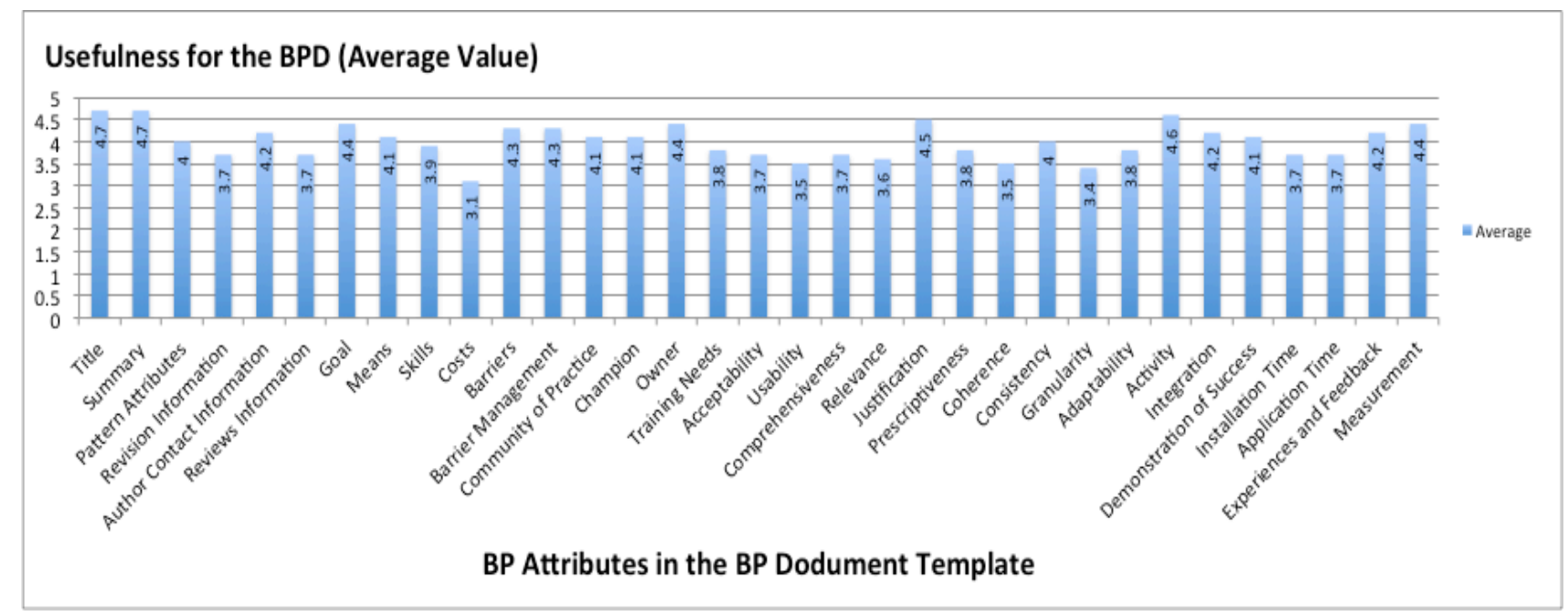

Figure 5. The overall assessed average value for usefulness for each of the 33 attributes in the BP Document Template.

The answers to the semi-structured part of the interviews were analyzed using content analysis, and the most significant benefits and drawbacks that emerged are described below.

\section{Benefits of BP Document Template}

Table 4. Benefits of BP Document Template identified based on qualitative analysis of interview data

\begin{tabular}{|l|l|l|l|}
\hline Benefit & Description & $\begin{array}{l}\text { Number } \\
\text { of } \\
\text { responses }\end{array}$ & Examples of citations \\
\hline $\begin{array}{l}\text { Designer } \\
\text { support }\end{array}$ & $\begin{array}{l}\text { The template } \\
\text { supports } \\
\text { experienced and } \\
\text { non-experienced } \\
\text { knowledge } \\
\text { engineers with } \\
\text { document BPs }\end{array}$ & 5 & $\begin{array}{l}\text { R3: "For design of BPs it gives a good } \\
\text { outline of what should be included". }\end{array}$ \\
\hline $\begin{array}{l}\text { The template } \\
\text { encourages the }\end{array}$ & 6 & $\begin{array}{l}\text { R15: "You start thinking of the guidelines } \\
\text { as a checklist but I think you can definitely } \\
\text { use it to design BP". }\end{array}$ \\
\hline Uniformity & $\begin{array}{l}\text { R3: "I think it would provide some } \\
\text { uniformity for the users and for the }\end{array}$ \\
\hline
\end{tabular}




\begin{tabular}{|c|c|c|c|}
\hline & $\begin{array}{l}\text { knowledge } \\
\text { engineer to ensure } \\
\text { that the BPs are } \\
\text { documented in a } \\
\text { uniform and } \\
\text { standardized way }\end{array}$ & & $\begin{array}{l}\text { organizations". } \\
\text { R8: "Standard format makes it easy and } \\
\text { facilitates the ability to analyze data } \\
\text { content". }\end{array}$ \\
\hline Reusability & $\begin{array}{l}\text { The template } \\
\text { encourages the } \\
\text { knowledge } \\
\text { engineer to ensure } \\
\text { that the BP is } \\
\text { reusable }\end{array}$ & 4 & $\begin{array}{l}\text { R6: "This is very useful in term of reuse } \\
\text { knowledge and knowledge efficiency in BP } \\
\text { guidelines". } \\
\text { R16: "I think in certain context, you can } \\
\text { take necessary BP or in my business case } \\
\text { and adapt it and use it without reinventing } \\
\text { the wheels." }\end{array}$ \\
\hline Relevance & $\begin{array}{l}\text { The template } \\
\text { encourages the } \\
\text { knowledge } \\
\text { engineer to focus } \\
\text { on BPs that are } \\
\text { relevant and } \\
\text { useful for the } \\
\text { organization }\end{array}$ & 4 & $\begin{array}{l}\mathrm{R} 9: \text { "...allow the correct person to provide } \\
\text { relevant information". }\end{array}$ \\
\hline Justification & $\begin{array}{l}\text { The template } \\
\text { encourages the } \\
\text { knowledge } \\
\text { engineer to ensure } \\
\text { that the BP } \\
\text { includes evidence }\end{array}$ & 4 & $\begin{array}{l}\text { R6: "To apply BP according to this system } \\
\text { to make sure that people understand the BP. } \\
\text { To get the feedback from people who apply } \\
\text { BPs. This feedback gives practitioners an } \\
\text { insight for how BP solves the problem". } \\
\text { R16: "it improves the quality of the } \\
\text { submissions so it provides evidence...". }\end{array}$ \\
\hline Efficiency & $\begin{array}{l}\text { The template } \\
\text { encourages } \\
\text { knowledge } \\
\text { engineers to } \\
\text { document the BPs } \\
\text { in such a way that } \\
\text { users can identify } \\
\text { and apply them } \\
\text { efficiently }\end{array}$ & 5 & $\begin{array}{l}\text { R6: "This is very useful in term of reuse } \\
\text { knowledge and knowledge efficiency in BP } \\
\text { guidelines". }\end{array}$ \\
\hline Effectiveness & $\begin{array}{l}\text { The template } \\
\text { encourages } \\
\text { knowledge } \\
\text { engineers to } \\
\text { document the BPs } \\
\text { in such a way that } \\
\text { users can identify } \\
\text { and apply them } \\
\text { effectively }\end{array}$ & 2 & $\begin{array}{l}\text { R4: "They will see the impact of such an } \\
\text { initiative, they will look at it from different } \\
\text { perspectives. Effectiveness gained and time } \\
\text { for implementation, cost, these guidelines } \\
\text { look very holistically". }\end{array}$ \\
\hline $\begin{array}{l}\text { Completenes } \\
\text { s }\end{array}$ & $\begin{array}{l}\text { The template } \\
\text { encourages the } \\
\text { knowledge }\end{array}$ & 5 & $\begin{array}{l}\text { R4: "You covered the entire picture and } \\
\text { that what I see in this. You have different } \\
\text { perspectives. There is no chance for any }\end{array}$ \\
\hline
\end{tabular}




\begin{tabular}{|c|c|c|c|}
\hline & $\begin{array}{l}\text { engineer to } \\
\text { provide } \\
\text { complete } \\
\text { description of the } \\
\text { BP }\end{array}$ & & $\begin{array}{l}\text { particular problem area or issued to be } \\
\text { unanswered or not thought of". } \\
\text { R9: "You have a list of criteria basically } \\
\text { that characterize a complete BPD so it } \\
\text { makes it easy to go through and see if you } \\
\text { include all these areas both /.../ for } \\
\text { submitter and the interviewer". }\end{array}$ \\
\hline Consistency & $\begin{array}{l}\text { The template } \\
\text { encourages the } \\
\text { knowledge } \\
\text { engineer to ensure } \\
\text { that the BP is } \\
\text { described in a } \\
\text { consistent way }\end{array}$ & 3 & $\begin{array}{l}\text { R7: "It makes it easier for people to be } \\
\text { consistent". } \\
\text { R10: "You ensure the quality output. /.../ } \\
\text { Then, you have consistency in the } \\
\text { outcomes". }\end{array}$ \\
\hline $\begin{array}{l}\text { Contextualiza } \\
\text {-tion }\end{array}$ & $\begin{array}{l}\text { The template } \\
\text { encourages } \\
\text { knowledge } \\
\text { engineers to } \\
\text { document the BP } \\
\text { in such a way that } \\
\text { users can } \\
\text { understand the BP } \\
\text { context }\end{array}$ & 1 & $\begin{array}{l}\text { R16: "The benefits I think in certain } \\
\text { context, you can take necessary BP or in my } \\
\text { business case and adapt it and use it } \\
\text { without reinventing the wheels". }\end{array}$ \\
\hline
\end{tabular}

\section{Drawbacks of BP Document Template}

Table 5. Drawbacks of BP Document Template identified based on qualitative analysis on interview data

\begin{tabular}{|c|c|c|c|}
\hline Drawback & Description & $\begin{array}{l}\text { Number } \\
\text { of } \\
\text { response }\end{array}$ & Example of citations \\
\hline $\begin{array}{l}\text { Extensive } \\
\text { resources } \\
\text { needs }\end{array}$ & $\begin{array}{l}\text { The template } \\
\text { requires } \\
\text { extensive } \\
\text { resources to } \\
\text { store, implement } \\
\text { and apply it }\end{array}$ & 5 & $\begin{array}{l}\text { R9: "The negative side is that someone may } \\
\text { look at a long list of a criteria or guidelines } \\
\text { and just say I am not going to take the time to } \\
\text { make a submission into the system". } \\
\text { R10: "It takes a long time. If you give it to a } \\
\text { user, it is long". }\end{array}$ \\
\hline Complexity & $\begin{array}{l}\text { The template is } \\
\text { too complex for } \\
\text { a simple case of } \\
\text { BP }\end{array}$ & 1 & $\begin{array}{l}\text { R5: "The biggest risk is excessive rigor in a } \\
\text { simple situation where heuristic BP may be } \\
\text { better than these guidelines. I think also, there } \\
\text { are some situations where guidelines simply } \\
\text { will not be useful. I refer to an emergent or } \\
\text { entirely novel undertaking where an } \\
\text { organization is attending to something that is } \\
\text { completely new". }\end{array}$ \\
\hline
\end{tabular}


Reduction of The template 2 creativity and innovation reduces creativity and innovation
R6: "If you have guidelines, it gives you outlines for the work but it may trick the creativity, and innovation of people".

\section{Suggested changes of BP Document Template}

Table 6. Suggested changes of BP Document Template identified based on qualitative analysis on interview data

\begin{tabular}{|l|l|l|}
\hline Change & $\begin{array}{l}\text { Number } \\
\text { of } \\
\text { response }\end{array}$ & Example of citations \\
\hline $\begin{array}{l}\text { Add organizational } \\
\text { culture as an attribute } \\
\text { and related values }\end{array}$ & 1 & $\begin{array}{l}\text { R8: "Add elements regarding organizational culture } \\
\text { to facilitate adaptation of the template". }\end{array}$ \\
\hline $\begin{array}{l}\text { Add Lessons learned as } \\
\text { an attribute }\end{array}$ & 1 & $\begin{array}{l}\text { R4: "In terms of adding, the template should have } \\
\text { some component in terms of lessons learned from a } \\
\text { particular industry or organization. There should be } \\
\text { some component cover that". }\end{array}$ \\
\hline $\begin{array}{l}\text { Add metrics supporting } \\
\text { measurement of the } \\
\text { template }\end{array}$ & 1 & $\begin{array}{l}\text { R7: "Suggest information about measurement and } \\
\text { metrics. That is what people struggle with the most". }\end{array}$ \\
\hline Prioritize attributes & 1 & $\begin{array}{l}\text { R9: "I think it may be good to indicate which } \\
\text { guidelines are more critical and you have high } \\
\text { priority. So someone who has limited time to vote for } \\
\text { it. Would know that certain guidelines are mandatory } \\
\text { and they have to provide information in those areas } \\
\text { where they can submit into the database". }\end{array}$ \\
\hline
\end{tabular}

\section{Concluding Remarks}

Through literature studies, expert interviews and demonstrations, a BP Document Template has been designed and evaluated. From a practical point of view, the template can support BP designers in creating high-quality BP descriptions. Furthermore, it can help BP managers in evaluating BPs. BPs described by means of the template will also be structured in such a way that users can more easily understand and apply them. Thus, the BP Document Template is useful for BP designers, BP managers as well as BP users. The paper also makes a theoretical contribution by consolidating, integrating and extending existing results on $\mathrm{BP}$ document structures.

The demonstration and evaluation studies have highlighted the following benefits of the proposed template: 
- Designer support - The template supports experienced and non-experienced knowledge engineers to document BPs

- Uniformity - The template encourages the knowledge engineer to ensure that the BPs are documented in a uniform and standardized way

- Efficiency - The template encourages knowledge engineers to document the BPs in such a way that users can identify and apply them efficiently

- Completeness - The template encourages the knowledge engineer to provide a complete description of the BP

The studies have also identified some potential drawbacks of the template:

- Extensive resource needs - The template requires extensive resources to store, implement and apply it

- Complexity - The template is too complex for a simple case of BP

- Effects on creativity and innovation - The template reduces creativity and innovation

These drawbacks offer suggestions for future work. The complexity of the template can be countered by supporting flexibility in its use, e.g. by ranking the included BP attributes so that a user can easily select among them in order to construct a customized template. The resource need can also be addressed by flexibility and customization, as well as tool support that enables reuse of $\mathrm{BP}$ document components. The issue of reduced creativity and innovation is common for many structured methods, including template-based ones, and needs to be taken seriously. It can be addressed by complementing the template with suggested ways-of-working that encourage creative and imaginative solutions.

\section{References}

Aggestam, L., Persson, A. (2010), Increasing The Quality in IT-Supported Knowledge Repositories: Critical Success Factors for Identifying Knowledge, $43^{\text {rd }}$ Hawaii International Conference on System Sciences (HICSS), Honolulu, HI, USA.

Alwazae, M.M.S., Perjons, E., Kjellin, H. (2014), Quality Measures for Documentation of Best Practices, $47^{\text {th }}$ Hawaii International Conference on System Sciences(HICSS), HI, USA, 3410-3419.

Arthur, J.D., Stevens, K.T. (1990), Document Quality Indicators: A Framework for Assessing Documentation Adequacy, Virginia Polytechnic Institute, State University.

Asoh, D., Belardo, S., Neilson, R. (2002), Knowledge Management: Issues, Challenges and Opportunities for Governments in the New Economy, System Sciences, HICSS. Proceedings of the $35^{\text {th }}$ Annual Hawaii International Conference on Information System, 1745-1754. 
Asrofah, T., Zailani, S., Fernando, Y. (2010), Best Practices for the Effectiveness of Benchmarking in the Indonesian Manufacturing Companies, Emerald Group Publishing Limited, Benchmarking: An International Journal, Vol. 17 No. 1, 115-143.

Axelsson K., Melin U., Söderström F. (2011), Analyzing Best Practice and Critical Success Factors in A Health Information System Case - Are there any Shortcuts to Successful IT Implementation?, In $19^{\text {th }}$ European Conference on Information Systems, Helsinki, Finland, 2157-2168.

Barclay, C., Osei-Bryson, K-M. (2010), An Exploration of Knowledge Management Practices in IT Projects: A Case Study Approach, AMCIS 2010 Proceedings. Paper 452.

Barrett, P., Stanley, C. (1999), Better Construction Briefing. Blackwell Science, John Wiley \& Sons.

Barsalou, L.W. (2003), Abstraction in Perceptual Symbol Systems, Philosophical Transactions of the Royal Society of London, Series B: Biological Sciences, 358, 1177-1187.

Barsalou, L.W., Hale, C.R. (1993), Components of Conceptual Representation: From Feature Lists to Recursive Frames, In Iven Van Mechelen, James Hampton, Ryszard S. Michalski, and Peter Theuns. Categories and Concepts: Theoretical Views and Inductive Data Analysis. London: Academic Press, 97-144.

Beaumont, N. (2005), Best Practice in Australian Manufacturing Sites, Elsevier Ltd, Technovation, Vol. 25, 1291-1297.

Bider, I., Johannesson, P., Perjons, E. (2012), Design Science Research as Movement Between Individual and Generic Situation-Problem-Solution Spaces, In Baskerville R., De Marco, M., Spagnoletti, P. (eds.) Organizational Systems. An Interdisciplinary Discourse, Springer.

Bubenko, J.A., Persson, A., Stirna, J. (2001), User Guide of the Knowledge Management Approach Using Enterprise Knowledge Patterns, Deliverable D3, IST Programme Project Hypermedia and Pattern Based Knowledge Management for Smart Organizations. Project No. IST-2000-28401. Department of Computer and Systems Sciences, Royal Institute of Technology, Stockholm, Sweden, Accessed 24 August 2014:

http://www.dsv.su.se/ js/ekd user guide.html

Burke, L.A., Hutchins, H.M. (2008), A Study of Best Practices in Training Transfer and Proposed Model of Transfer, Human Resource Development Quarterly, Vol. 19 No. 2, 107128.

Chourides, P., Longbottom, D., Murphy, W. (2003), Excellence in Knowledge Management: An Empirical Study to Identify Critical Factors and Performance Measures, Measuring Business Excellence, Vol. 7 No. 2, 29-45. 
Dautovic, A., Plosch, R., Saft, M. (2011), Automatic Checking of Quality Best Practices in Software Development Documents, Quality Software (QSIC), $11^{\text {th }}$ International Conference on Quality Software, IEEE Computer Society, 13-14 July, Madrid, 208-217.

Dalkir, K. (2011), Knowledge Management in Theory and Practice. The MIT Press.

Dana, L.E., Smyrnios, K.X. (2010), Family Business Best Practices: Where from and where to, Elsevier Ltd, Journal of Family Business Strategy, 1, 40-53.

Dani, S.S., Harding, J.A., Case, K., Young, R.I.M., Cochrane, S., Gao, J., Baxter, D. (2006), A Methodology for Best Practice Knowledge Management, Proceedings of the Institution of Mechanical Engineers, Part B: Journal of Engineering Manufacture, Vol. 220 No. 10, 17171728.

Davies, A.J., Kochhar, A.K. (2002), Manufacturing Best Practice and Performance Studies: A Critique, International Journal of Operations \& Production Management, MCB University Press, Vol. 22 No. 3, 289-305.

Dedoose, (2015), Great Research Made Easy, Dedoose website, accessed 10 June 2015:

\section{http://www.dedoose.com/}

Dinur, A., Hamilton, R., Inkpen, A. (2009), Critical Context and International Intrafirm BestPractice Transfers, Elsevier Inc, Journal of International Management, Vol. 15, 432-446.

Done, A., Voss, C., Rytter, N. (2011), Best Practice Interventions: Short-Term Impact and Long-Term Outcomes, Elsevier B.V, Journal of Operations Management, Vol. 29 No. 5, July 2009, 500-513.

Jarrar, Y.F., Zairi, M. (2000), Internal Transfer of Best Practice for Performance Excellence: A Global Survey, Benchmarking: An International Journal, MCB University Press, Vol. 7 No. 4, 239-246.

Dyer, G., McDonough, B. (2001), The State of KM. Knowledge Management, 4 (5), 31-36.

Fragidis, G., Tarabanis, K. (2006), From Repositories of Best Practices to Networks of Best Practices, International Conference on Management of Innovation and Technology, IEEE, 370-374.

Gold, A.H., Malhotra, A., Segars, A.H. (2001), Knowledge Management: An Organizational Capabilities Perspective, Journal of Management Information Systems, Vol. 18 No. 1, 185214.

Goodman, B.D., Goldman, S.N. (2007), Freeing Creativity by Understanding the Role of Best Practices, IEEE Engineering Management Conference, Austin, TX,USA, 308-311. 
Graupner, S., Motahari-Nezhad, H.R., Singhal, S., Basu, S. (2009), Making Processes from Best Practice Frameworks Actionable, Enterprise Distributed Object Computing Conference Workshops, $13^{\text {th }}$ IEEE, 1-4 September, 25-34.

Guo, Z., Sheffield, J. (2008), A Paradigmatic and Methodological Examination of Knowledge Management Research: 2000 to 2004, Decision Support Systems, Vol. 44 No.3, 673-688.

Hargis, G., Carey, M., Hernandez, A.K., Hughes, P., Longo, D., Rouiller, S., Wilde, E. (2014), Developing Quality Technical Information: A Handbook for Writers and Editors, $3^{\text {rd }}$ Edition. IBM Press Book.

Hevner, A.R., March, S.T., Park, J., Ram, S. (2004), Design Science in Information Systems Research, MIS Quarterly, Vol. 28 No. 1, 75-105.

ISO/IEC 26514:2008. (2008), Systems and Software Engineering -- Requirements for Designers and Developers of User Documentation, accessed 10 March 2013:

http://www.iso.org/iso/catalogue_detail? csnumber=43073

Jashapara, A. (2011), Knowledge Management: An Integrated Approach, $2^{\text {nd }}$ Edition. Pearson Education, Harlow, Essex.

Johannesson, P., Perjons, E. (2014), An Introduction to Design Science, Springer International Publishing, Switzerland.

Mansar, S., Reijers, H. (2007), Best Practices in Business Process Redesign: Use and Impact, Business Process Management Journal, Emerald Group Publishing Limited, Vol. 13 No. 2, 193-213.

Motahari-Nezhad, H.R.M., Graupner, V., Bartolini, C. (2010), A Framework for Modeling and Enabling Reuse of Best Practice IT Processes, Business Process Management Workshops, 226-231.

Netland, T., Alfnes, E. (2011), Proposing a Quick Best Practice Maturity Test for Supply Chain Operations, Measuring Business Excellence, Vol. 15 No.1, 66-76.

Niwe, M., Stirna, J. (2010), Examining Knowledge Capture for the B2B Domain, International Journal for Infonomics Society (IJI), Vol. 3 No. 2, 353-362.

Niwe, M., Stirna, J. (2009), Organizational Patterns for B2B Environments - Validation and Comparison, Enterprise, Business-Process and Information Systems Modeling, Lecture Notes in Business Information Processing Vol. 29, 394-406.

Lewins, A., Silver, C. (2007), Using Software in Qualitative Research: A Step-by- Step Guide. Sage Publications, Inc.: Thousand Oaks, CA. 
O’Dell, C., Grayson, C.J. (1998), If only we Knew what we Know: Identification and Transfer of Internal Best Practices, California Management Review, Vol. 40 No. 3, 154-174.

Olfman, L., Bostrom, R., Sein, M. (2003), A Best-Practice Based Model for Information Technology Learning Strategy Formulation, SIGMIS Conference ACM.03,10-12 April 2003, Pennsylvania, 75-86.

Pfeffer, J., Sutton, R. (2006), Hard Fact, Dangerous Half-Truths and Total Nonsense, Boston MA: Harvard Business School Press.

Reddy, W., McCarthy, S. (2006), Sharing Best Practice, International Journal of Health Care Quality Assurance, Vol. 19 No. 7, 594-598.

Persson A., Stirna J., Aggestam L. (2008), How to Disseminate Professional Knowledge in Healthcare: The Case of Skaraborg Hospital, Journal of Cases on Information Technology, 3, $42-64$.

Renzl, B., Matzler, K., Hinterhuber, H. (2006), The Future of Knowledge Management, Palgrave Macmillan, New York.

Shull, F., Turner, R. (2005), An Empirical Approach to Best Practice Identification and Selection: The US Department of Defense Acquisition Best Practices Clearinghouse, Proceedings of International Symposium on Empirical Software Engineering, Australia, 133140.

Smith, F.I., Kisamore, J.L., Stone, T.H., Jawahar, I.M. (2010), Decision-Making Biases and Affective States: Their Potential Impact on Best Practice Innovations, Canadian Journal of Administrative Sciences, ASAC, John Wiley \& Sons, Lted, 277-291.

Szulanski, G. (1996) Exploring Internal Stickiness: Impediments to the Transfer of Best Practice within the Firm, Strategic Management Journal, John Wiley \& Sons, Vol. 17, 27-43.

Tabrizi, R.S., Ebrahimi, N., Al-Marwai, S.A. (2011), On the Comparison of KM Criteria Classifications, World Conference on Information Technology, Procedia Computer Science, 3, 684-690.

Timbrell, G., Andrews, N., Gable, G. (2001), Impediments to Inter-Firm Transfer of Best Practice: in an Enterprise Systems Context, AMCIS 2001 Proceedings, Paper 211.

Vesely, A. (2011), Theory and Methodology of Best Practice Research: A Critical Review of the Current State, Central European Journal of Public Policy, 2, 98-117.

Watson, G.H. (2007), Strategic Benchmarking Reloaded with Six Sigma: Improve your Company's Performance Using Global Best Practice. John Wiley \& Sons, Inc., Hoboken, New Jersey. 
Webster, J., Watson, R.T. (2002), Analyzing the Past to Prepare for the Future: Writing a Literature Review, Journal MIS Quarterly, Vol. 26 No.2.

Whittle, S., Smith, S., Tranfield, D., Foster, M. (1992), Implementing Total Quality: The Downside of Best Practice, $7^{\text {th }}$ Annual Conference of the Operations Management Association on International Operations, Crossing Borders in Manufacturing and Service, UMIST, Manchester, 23-24 June, 247-252.

Wolfswinkel, J.F., Furtmueller, E., Wilderom, C. (2013), Using Grounded Theory as a Method for Rigorously Reviewing Literature, European Journal of Information Systems, 22, 45-55.

Xu, Y., Yeh, C. (2010), An Optimal Best Practice Selection Approach, Computational Science and Optimization (CSO), Third International Joint Conference on Computational Science and Optimization, No. 2, 28-31 May 2010, 242-246.

Zairi, M., Ahmed, P. (1999), Benchmarking Maturity as we Approach The Millennium? Total Quality Management, Taylor \& Francis Ltd, Vol. 10 No. 4-5, 810-816.

Zandi, F., Tavana, M. (2011), A Fuzzy Multi-Objective Balanced Scorecard Approach for Selecting an Optimal Electronic Business Process Management Best Practice (e-BPMBP), Business Process Management Journal, Vol. 17 No. 1, 147-178.

Zhu, L., Staples, M., Gorton, I. (2007), An Infrastructure for Indexing and Organizing Best Practices, Second International Workshop on Realizing Evidence-Based Software Engineering, 20-26 May, IEEE, Computer Society Washington, DC, USA.

\section{Appendix I}

The First Tentative BP Document Template (Alwazae et al., 2014)

\begin{tabular}{|l|l|}
\hline Component & Attributes \\
\hline General style & $\begin{array}{l}\text { 1. BP shall include the essential elements of its nature. } \\
\text { 2. BP shall contain a dramatic climax or some information that } \\
\text { highlights what is most important in the BP. }\end{array}$ \\
\hline $\begin{array}{l}\text { 3. BP shall contain information of the date when it was written and who } \\
\text { wrote the BP. }\end{array}$ \\
\hline $\begin{array}{l}\text { Summary of } \\
\text { BP }\end{array}$ & $\begin{array}{l}\text { 4. BP's summary shall encompass the most significant and identifiable } \\
\text { aspects of the BP. }\end{array}$ \\
$\begin{array}{l}\text { 5. BP's summary shall contain information about the area/field in which } \\
\text { the BP is to be applied. }\end{array}$ \\
\hline $\begin{array}{l}\text { 6. BP's description shall include a summary or abstract outlining the BP. } \\
\text { using the BP for }\end{array}$ & $\begin{array}{l}\text { 7. BP shall describe the advantageous outcome of its application. } \\
\text { 8. BP shall describe in which respect it is better than other alternative } \\
\text { practices. }\end{array}$ \\
\hline
\end{tabular}




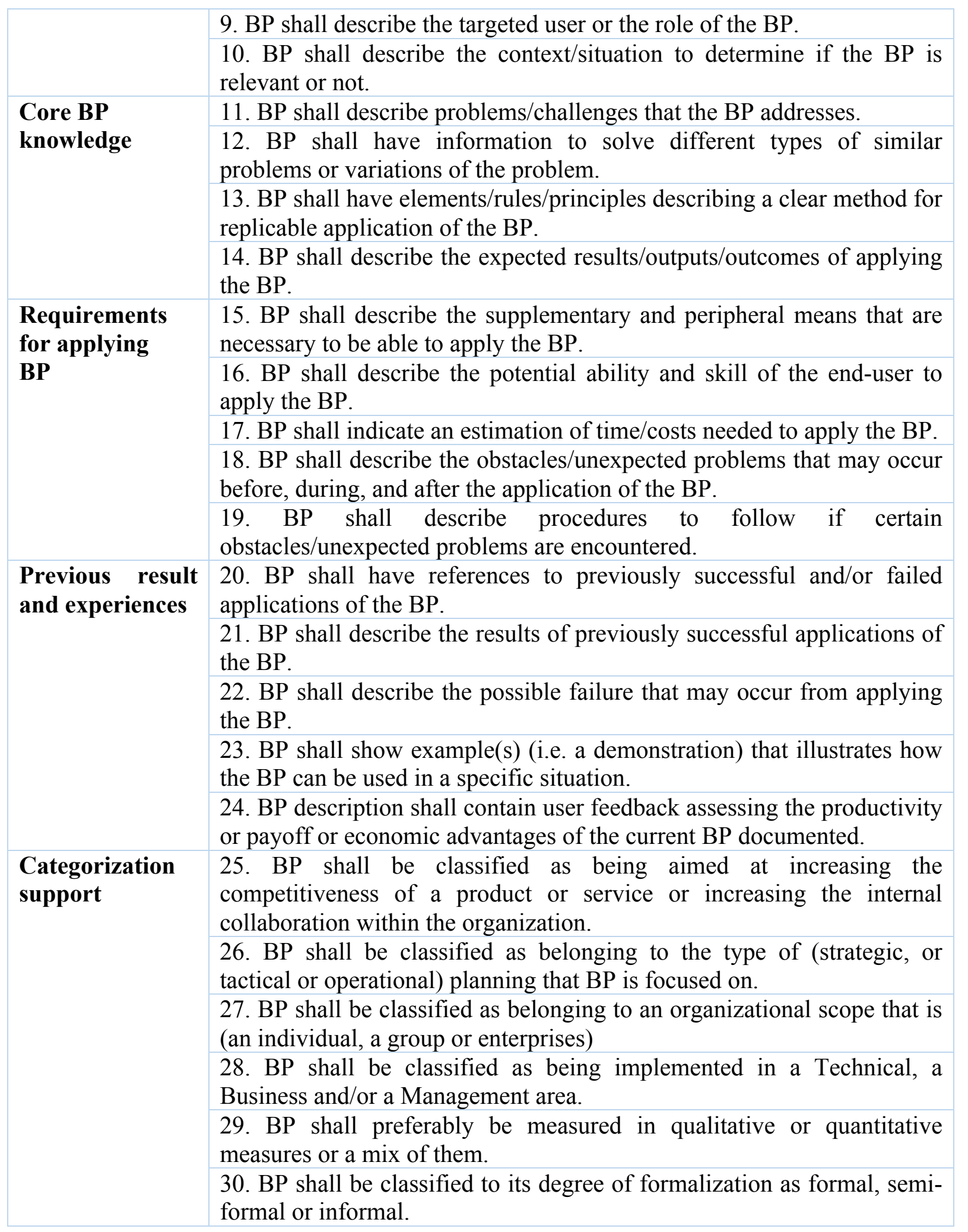

\section{Appendix II}

The Second Tentative Document Template

\begin{tabular}{l|llll} 
Category & Sub- & Definition & Concepts & Definition \\
\hline
\end{tabular}




\begin{tabular}{|c|c|c|c|c|}
\hline & category & & & \\
\hline \multirow[t]{3}{*}{$\begin{array}{l}\text { BP } \\
\text { Representation: } \\
\text { Related to } \\
\text { documentation } \\
\text { and presentation } \\
\text { of a BP }\end{array}$} & $\begin{array}{l}\text { Presentation } \\
\text { Structure }\end{array}$ & $\begin{array}{l}\text { Presentation } \\
\text { Structure is a } \\
\text { template to } \\
\text { represent a BP }\end{array}$ & $\begin{array}{l}\text { Pattern } \\
\text { Attributes }\end{array}$ & $\begin{array}{lr}\text { Contains } & \text { attributes } \\
\text { often used in } \\
\text { pattern } \\
\text { descriptions, such } \\
\text { as } \\
\text { solution problem, } \\
\text { context }\end{array}$ \\
\hline & \multirow[t]{2}{*}{$\begin{array}{l}\text { Document } \\
\text { metadata }\end{array}$} & \multirow{2}{*}{$\begin{array}{l}\text { Document } \\
\text { metadata } \\
\text { provide } \\
\text { information } \\
\text { about aspects of } \\
\text { the document }\end{array}$} & $\begin{array}{l}\text { Revision } \\
\text { Information }\end{array}$ & $\begin{array}{l}\text { Information about } \\
\text { revisions and } \\
\text { reviews of the BP }\end{array}$ \\
\hline & & & $\begin{array}{l}\text { Author } \\
\text { Contact } \\
\text { Information }\end{array}$ & $\begin{array}{l}\text { Information about } \\
\text { author and contact } \\
\text { information }\end{array}$ \\
\hline \multirow[t]{6}{*}{$\begin{array}{l}\text { BP Actor: } \\
\text { Related to user } \\
\text { relationship and } \\
\text { BP actor resource }\end{array}$} & \multirow[t]{3}{*}{$\begin{array}{l}\text { BP actor } \\
\text { Resource }\end{array}$} & \multirow[t]{3}{*}{$\begin{array}{l}\text { BP actor } \\
\text { Resource is an } \\
\text { individual, } \\
\text { group or role } \\
\text { involved in the } \\
\text { use of a BP }\end{array}$} & $\begin{array}{l}\text { Community } \\
\text { Of Practice }\end{array}$ & $\begin{array}{l}\text { Group of people } \\
\text { who share a } \\
\text { concern or a } \\
\text { passion } \\
\text { something they do } \\
\text { and learn how to do } \\
\text { it better, and who } \\
\text { may therefore use } \\
\text { the BP }\end{array}$ \\
\hline & & & Champion & $\begin{array}{l}\text { An individual or } \\
\text { role that facilitates } \\
\text { and supports the } \\
\text { success of the BP }\end{array}$ \\
\hline & & & Owner & $\begin{array}{l}\text { An individual, role, } \\
\text { unit or organization } \\
\text { that owns the BP }\end{array}$ \\
\hline & \multirow[t]{3}{*}{$\begin{array}{l}\text { User } \\
\text { Relationship }\end{array}$} & \multirow{3}{*}{$\begin{array}{l}\text { User } \\
\text { relationship is a } \\
\text { relationship } \\
\text { between a user } \\
\text { and a BP }\end{array}$} & $\begin{array}{l}\text { Training } \\
\text { needs }\end{array}$ & $\begin{array}{l}\text { The degree to } \\
\text { which a person has } \\
\text { to be trained in } \\
\text { order to use the BP }\end{array}$ \\
\hline & & & Usability & $\begin{array}{l}\text { The degree to } \\
\text { which the BP is } \\
\text { easy to use }\end{array}$ \\
\hline & & & Acceptability & $\begin{array}{l}\text { The degree of } \\
\text { acceptance of the } \\
\text { BP to be used by } \\
\text { domain experts for } \\
\text { resolving } \\
\text { particular problem } \\
\text { of interest }\end{array}$ \\
\hline $\begin{array}{l}\text { BP Properties: } \\
\text { Related to } \\
\text { Internal BP } \\
\text { characteristics } \\
\text { and problem } \\
\text { relationship }\end{array}$ & $\begin{array}{l}\text { Problem } \\
\text { Relationship }\end{array}$ & $\begin{array}{l}\text { Problem } \\
\text { Relationship is } \\
\text { the relationship } \\
\text { between a } \\
\text { business } \\
\text { problem and a }\end{array}$ & $\begin{array}{l}\text { Comprehensi } \\
\text { veness }\end{array}$ & $\begin{array}{l}\text { The degree to } \\
\text { which the BP } \\
\text { offers } \\
\text { comprehensive and } \\
\text { complete view of } \\
\text { the problem under }\end{array}$ \\
\hline
\end{tabular}




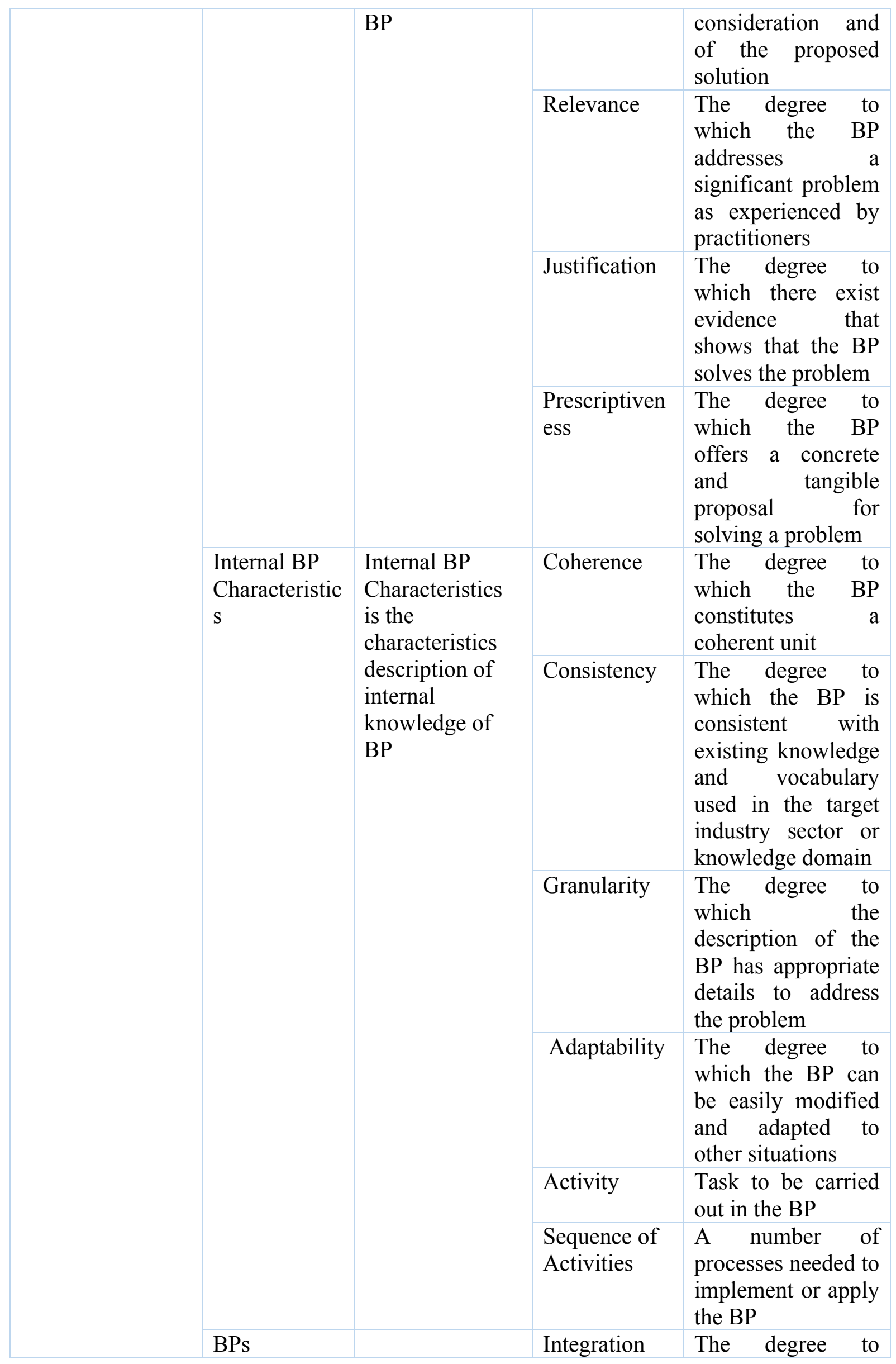




\begin{tabular}{|c|c|c|c|c|}
\hline & relationships & & & $\begin{array}{l}\text { which the BP is } \\
\text { integrated with } \\
\text { other BPs and KM } \\
\text { components }\end{array}$ \\
\hline \multirow{5}{*}{$\begin{array}{l}\text { BP } \\
\text { Implementation: } \\
\text { Related to } \\
\text { evaluate and } \\
\text { apply BP }\end{array}$} & \multirow[t]{3}{*}{ Application } & \multirow{3}{*}{$\begin{array}{l}\text { Application is } \\
\text { about applying } \\
\text { the BP in } \\
\text { practice }\end{array}$} & $\begin{array}{l}\text { Demonstratio } \\
\mathrm{n} \text { of Success }\end{array}$ & $\begin{array}{l}\text { A case where the } \\
\text { BP is successfully } \\
\text { demonstrated }\end{array}$ \\
\hline & & & $\begin{array}{l}\text { Installation } \\
\text { Time }\end{array}$ & $\begin{array}{l}\text { Time it takes to } \\
\text { introduce and } \\
\text { implement the BP } \\
\text { in an organization }\end{array}$ \\
\hline & & & $\begin{array}{l}\text { Application } \\
\text { Time }\end{array}$ & $\begin{array}{l}\text { Time it takes to } \\
\text { carry out the BP in } \\
\text { an organization }\end{array}$ \\
\hline & \multirow[t]{2}{*}{ Evaluation } & \multirow{2}{*}{$\begin{array}{l}\text { Evaluation is a } \\
\text { systematic } \\
\text { determination of } \\
\text { a BP merits, } \\
\text { worth and } \\
\text { significance }\end{array}$} & $\begin{array}{l}\text { Experiences } \\
\text { and Feedback }\end{array}$ & $\begin{array}{l}\text { Users' opinions, } \\
\text { advices } \\
\text { experiences }\end{array}$ \\
\hline & & & Measurement & $\begin{array}{l}\text { An indicator for the } \\
\text { quality and } \\
\text { performance of the } \\
\text { BP }\end{array}$ \\
\hline
\end{tabular}

\section{Appendix III}

Corresponding articles for each BP attributes in the Second Tentative Document Template

\begin{tabular}{|l|l|}
\hline BP Attributes & Corresponding Articles \\
\hline Pattern Attribute & $\begin{array}{l}\text { Niwe \& Stirna (2009), Persson et al, (2008), Niwe \& Stirna, } \\
\text { (2010) \& Dani et al, (2006). }\end{array}$ \\
\hline $\begin{array}{l}\text { Revision } \\
\text { Information }\end{array}$ & $\begin{array}{l}\text { Zhu et al, (2007), Asoh et al, (2002), Zairi \& Ahmed (1999), } \\
\text { Niwe \& Stirna (2009), Niwe \& Stirna (2010), Graupner et al, } \\
\text { (2009), Persson et al, (2008), Motahari-Nezhad et al, (2010), } \\
\text { O’Dell \& Grayson (1998). }\end{array}$ \\
\hline $\begin{array}{l}\text { Author Contact } \\
\text { Information }\end{array}$ & $\begin{array}{l}\text { Dinur et al, (2009), O’Dell \& Grayson (1998), Done et al, } \\
\text { (2011), Dani et al, (2006), Niwe \& Stirna (2010), Burke \& } \\
\text { Hutchins (2008), Zhu et al, (2007), Graupner et al, (2009), } \\
\text { Jarrar \& Zairi (2000), O’Dell \& Grayson (1998). }\end{array}$ \\
\hline $\begin{array}{l}\text { Community } \\
\text { Practice }\end{array}$ & $\begin{array}{l}\text { Shull \& Turner (2005), Fragidis \& Tarabanis (2006), Olfman } \\
\text { et al, (2003), Asoh et al, (2002), Shull \& Turner (2005), } \\
\text { O’Dell \& Grayson (1998), Dani et al, (2006). }\end{array}$ \\
\hline Champion & $\begin{array}{l}\text { Smith et al, (2010), Beaumont (2005), Asrofah et al, (2010), } \\
\text { Persson et al, (2008), Done et al, (2011), Olfman et al, (2003), } \\
\text { Zairi \& Ahmed (1999). }\end{array}$ \\
\hline Owner & $\begin{array}{l}\text { Szulanski (1996), Timbrell et al, (2001), Jarrar \& Zairi (2000), } \\
\text { Persson et al, (2008), Olfman et al, (2003), Shull \& Turner } \\
\text { (2005). }\end{array}$ \\
\hline
\end{tabular}




\begin{tabular}{|c|c|}
\hline Training & $\begin{array}{l}\text { Burke \& Hutchins (2008), Olfman et al, (2003), Dani et al, } \\
\text { (2006), Reddy \& McCarthy (2006), Persson et al, (2008) \& } \\
\text { Jarrar \& Zairi (2000). }\end{array}$ \\
\hline Acceptability & $\begin{array}{l}\text { Z\&i \& Tavana (2011), Shull \& Turner (2005) \& Done et al, } \\
\text { (2011), Timbrell et al, (2001), Niwe \& Stirna (2010), Zairi \& } \\
\text { Ahmed (1999), Reddy \& McCarthy (2006), Shull \& Turner } \\
\text { (2005), O’Dell \& Grayson (1998), Dani et al, (2006), } \\
\text { Graupner et al, (2009), Smith et al, (2010) \& Szulanski (1996). }\end{array}$ \\
\hline Usability & $\begin{array}{l}\text { Axelsson et al, (2011), Mansar \& Reijers (2007), Persson et al, } \\
\text { (2008), Shull \& Turner (2005), Smith et al, (2010), Szulanski } \\
\text { (1996), Jarrar \& Zairi (2000), Shull \& Turner (2005), Z\&i \& } \\
\text { Tavana (2011), Asoh et al, (2002), Dani et al, (2006), Reddy } \\
\& \text { McCarthy (2006), Niwe \& Stirna (2010), Niwe \& Stirna } \\
\text { (2009), Zairi \& Ahmed (1999). }\end{array}$ \\
\hline Comprehensiveness & $\begin{array}{l}\text { Xu \& Yeh (2010), Dana \& Smyrnios (2010) \& Niwe \& Stirna } \\
\text { (2009), Niwe \& Stirna (2010), Reddy \& McCarthy (2006), } \\
\text { Shull \& Turner (2005), O’Dell \& Grayson (1998), Beaumont } \\
\text { (2005), Timbrell et al, (2001), Asrofah et al, (2010), Motahari- } \\
\text { Nezhad et al, (2010), Persson et al, (2008) \& Graupner et al, } \\
\text { (2009). }\end{array}$ \\
\hline Relevance & $\begin{array}{l}\text { Zairi \& Ahmed (1999), Zhu et al, (2007), Persson et al, } \\
\text { (2008), Asrofah et al, (2010), Reddy \& McCarthy (2006), } \\
\text { Done et al, (2011), Fragidis \& Tarabanis (2006), Szulanski } \\
\text { (1996), Smith et al, (2010), Xu \& Yeh (2010), Niwe \& Stirna } \\
\text { (2009), Shull \& Turner (2005), Dani et al, (2006). }\end{array}$ \\
\hline Justification & $\begin{array}{l}\text { Dana \& Smyrnios (2010), O’Dell \& Grayson (1998), } \\
\text { Szulanski (1996), Done et al, (2011), Smith et al, (2010), Zhu } \\
\text { et al, (2007), O'Dell \& Grayson (1998), Persson et al, (2008), } \\
\text { Dinur et al, (2009), Niwe \& Stirna (2009) \& Timbrell et al, } \\
\text { (2001). }\end{array}$ \\
\hline Prescriptiveness & $\begin{array}{l}\text { Barclay \& Osei-Bryson (2010), Shull \& Turner (2005), Niwe } \\
\text { \& Stirna, (2009) \& Szulanski (1996). }\end{array}$ \\
\hline Coherence & $\begin{array}{l}\text { Persson et al, (2008), Davies \& Kochhar (2002), Dana \& } \\
\text { Smyrnios (2010), Niwe \& Stirna (2009), Reddy \& McCarthy } \\
\text { (2006), Shull \& Turner (2005), Done et al, (2011), Dani et al, } \\
\text { (2006), Graupner et al, (2009). }\end{array}$ \\
\hline Consistency & $\begin{array}{l}\text { Smith et al, (2010), Done et al, (2011), Barclay \& Osei-Bryson } \\
\text { (2010), Davies \& Kochhar (2002), Asrofah et al, (2010), Dana } \\
\text { \& Smyrnios (2010), Niwe \& Stirna (2009), Barclay \& Osei- } \\
\text { Bryson (2010), Shull \& Turner (2005), Axelsson et al, (2011), } \\
\text { Graupner et al, (2009) \& Jarrar \& Zairi (2000). }\end{array}$ \\
\hline Granularity & $\begin{array}{l}\text { Motahari-Nezhad et al, (2010), Mansar \& Reijers (2007), } \\
\text { Graupner et al, (2009), Niwe \& Stirna (2009), Szulanski } \\
\text { (1996), Persson et al, (2008), Shull \& Turner (2005) \& Dani et } \\
\text { al, (2006). }\end{array}$ \\
\hline Adaptability & $\begin{array}{l}\text { Chourides et al, (2003), Fragidis \& Tarabanis (2006), Smith et } \\
\text { al, (2010), Dani et al, (2006), Dana \& Smyrnios, (2010), Done } \\
\text { et al, (2011), Szulanski (1996), Reddy \& McCarthy (2006), } \\
\text { Zairi \& Ahmed (1999), Motahari-Nezhad et al, (2010), } \\
\text { Mansar \& Reijers (2007), Shull \& Turner (2005), O'Dell \& }\end{array}$ \\
\hline
\end{tabular}




\begin{tabular}{|c|c|}
\hline & $\begin{array}{l}\text { Grayson (1998), Persson et al, (2008), Asrofah et al, (2010), } \\
\text { Jarrar \& Zairi (2000) \& Niwe \& Stirna (2009). }\end{array}$ \\
\hline Activity & $\begin{array}{l}\text { Persson et al, (2008), Zairi \& Ahmed (1999), Beaumont } \\
\text { (2005), Jarrar \& Zairi (2000), Motahari-Nezhad et al, (2010), } \\
\text { Done et al, (2011), Dani et al, (2006), Graupner et al, (2009). }\end{array}$ \\
\hline Integration & $\begin{array}{l}\text { Dinur et al, (2009), Asoh et al, (2002), Olfman et al, (2003), } \\
\text { Persson et al, (2008), Dana \& Smyrnios, (2010), Szulanski } \\
\text { (1996), Graupner et al, (2009) \& Timbrell et al, (2001). }\end{array}$ \\
\hline $\begin{array}{l}\text { Demonstration of } \\
\text { Success }\end{array}$ & $\begin{array}{l}\text { Persson et al, (2008), Jarrar \& Zairi (2000), O’Dell \& Grayson } \\
\text { (1998), Dani et al, (2006), Dana \& Smyrnios, (2010) \& Zairi } \\
\text { \& Ahmed (1999). }\end{array}$ \\
\hline Installation Time & $\begin{array}{l}\text { Z\&i \& Tavana (2011), Asrofah et al, (2010), Burke \& } \\
\text { Hutchins (2008), Davies \& Kochhar (2002), Persson et al, } \\
\text { (2008), Mansar \& Reijers (2007), Done et al, (2011), Niwe \& } \\
\text { Stirna (2009) \& Jarrar \& Zairi (2000). }\end{array}$ \\
\hline Application Time & $\begin{array}{l}\text { Davies \& Kochhar (2002), Done et al, (2011), Dinur et al, } \\
\text { (2009), Motahari-Nezhad et al, (2010), Asoh et al, (2002), } \\
\text { Burke \& Hutchins (2008), Graupner et al, (2009), Persson et } \\
\text { al, (2008) \& Dani et al, (2006). }\end{array}$ \\
\hline $\begin{array}{l}\text { Experiences } \\
\text { Feedback }\end{array}$ & $\begin{array}{l}\text { Niwe \& Stirna (2010), Axelsson et al, (2011), Zhu et al, } \\
\text { (2007). Asoh et al, (2002), Fragidis \& Tarabanis (2006), } \\
\text { Szulanski (1996), Zairi \& Ahmed (1999), Motahari-Nezhad et } \\
\text { al, (2010), Xu \& Yeh (2010), Shull \& Turner (2005), Zhu et } \\
\text { al, (2007), Dinur et al, (2009), Mansar \& Reijers (2007), Niwe } \\
\text { \& Stirna (2009), Smith et al, (2010), Dani et al, (2006), } \\
\text { Persson et al, (2008) \& Jarrar \& Zairi (2000). }\end{array}$ \\
\hline Measurement & $\begin{array}{l}\text { Xu \& Yeh (2010), Chourides et al, (2003), Done et al, (2011), } \\
\text { Dana \& Smyrnios, (2010), Done et al, (2011), Niwe \& Stirna } \\
\text { (2010), Z\&i \& Tavana (2011), Davies \& Kochhar (2002), } \\
\text { Zairi \& Ahmed (1999), Dani et al, (2006), Shull \& Turner } \\
\text { (2005), Beaumont (2005), Timbrell et al, (2001) \& Smith et al, } \\
\text { (2010). }\end{array}$ \\
\hline
\end{tabular}

\section{Appendix IV}

\section{Correspondences between First Tentative BP Document Template and Second Tentative BP Document Template}

\section{First Tentative BP Document Second Tentative BP Document Template Template}

1. BP shall include the essential No correspondence but this is merged with the elements of its nature Summary attribute from the First Tentative BP Document Template)

2. BP shall contain a dramatic No correspondence but this is covered by the Summary climax or some information that attribute in the Final BP Document Template (and first highlights what is most presented in the First Tentative BP Document Template) important in the BP

3. BP shall contain information Revision Information, which is information about when 
of the date when it was written and who wrote the BP

7. BP shall describe the advantageous outcome of its application the BP was recently revised reviewed and renewed.

And Author Contact Information, which is author contact information exchange

No correspondence, but this was covered with four attributes that are:

Demonstration of success, which is a case where the BP is successfully demonstrated

Acceptability: The degree of acceptance of the BP to be used by domain experts for resolving a particular problem of interest.

Relevance: The degree to which the BP addresses a significant problem as experienced by practitioners Justification: The degree to which there exist evidence that shows that the BP solves the problem

8. BP shall describe in which respect it is better than other alternative practices

No correspondence, but this was covered with four attributes that are:

Demonstration of success, which is a case where the BP is successfully demonstrated

Acceptability: The degree of acceptance of the BP to be used by domain experts for resolving a particular problem of interest.

Relevance: The degree to which the BP addresses a significant problem as experienced by practitioners Justification: The degree to which there exist evidence that shows that the BP solves the problem

10. BP shall describe the No correspondence, but this attribute is covered by most context/situation to determine if of the attribute in the Final BP Document Template. It the $\mathrm{BP}$ is relevant or not can also be covered in the Pattern Attributes, which can contain Context as a value

11. BP shall describe No correspondence, but this was merged with Goal from problems/challenges that the BP the First Tentative BP Document Template. This addresses

12. BP shall have information to solve different types of similar problems or variations of the problem

13. BP shall have Activity, which is task to be carried out in the BP elements/rules/principles describing a clear method for replicable application of the BP

14. BP shall describe the expected results/ outputs/outcomes of applying the BP

17. BP shall indicate an Installation Time, which is time it takes to introduce and estimation of time/costs needed to apply the BP implement the BP in the organization And Application Time: Time it takes to carry out the BP 23. BP shall show example(s) Demonstration of Success, which is a process where a (i.e. a demonstration) that $\mathrm{BP}$ is successfully demonstrated 
illustrates how the BP can be used in a specific situation

20. BP shall have references to previously successful and/or failed applications of the $\mathrm{BP}$

21. BP shall describe the results of previously successful applications of the BP

24. BP description shall contain user feedback assessing the productivity or payoff or economic advantages of the current BP documented

25. BP shall be classified as being aimed at increasing the competitiveness of a product or service or increasing the internal collaboration within the organization

26. BP shall be classified as belonging to the type of (strategic, or tactical or operational) planning that $\mathrm{BP}$ is focused on

27. BP shall be classified as belonging to an organizational scope that is (an individual, a group or enterprises)

28. BP shall be classified as This attribute is one of six attributes aimed to be used being implemented in a mainly as indexing BPs and were therefore not of Technical, a Business and/or a interest for the Final BP Document Template Management area

29. BP shall preferably be This attribute is one of six attributes aimed to be used measured in qualitative or mainly as indexing BPs and were therefore not of quantitative measures or a mix interest for the Final BP Document Template of them

30. BP shall be classified to its This attribute is one of six attributes aimed to be used degree of formalization as mainly as indexing BPs and were therefore not of formal, semi-formal or informal interest for the Final BP Document Template

Experiences and Feedback, which is users' opinions, advices and experiences

Demonstration of Success, which is a case where a BP

Experiences and Feedback, which is users' opinions, advices and experiences

This attribute is one of six attributes aimed to be used mainly as indexing BPs and were therefore not of interest for the Final BP Document Template

This attribute is one of six attributes aimed to be used mainly as indexing BPs and were therefore not of interest for the Final BP Document Template

This attribute is one of six attributes aimed to be used mainly as indexing BPs and were therefore not of interest for the Final BP Document Template

\author{
sed
}

